\title{
A National Scale Assessment of Temporal Variations in Groundwater Discharge to Rivers: Malawi
}

\author{
Laura Kelly ${ }^{1,}$, , Douglas Bertram ${ }^{1}$, Robert Kalin ${ }^{1}$, Cosmo Ngongondo ${ }^{2}$, Hyde Sibande $^{3}$ \\ ${ }^{1}$ Department of Civil and Environmental Engineering, University of Strathclyde, Glasgow, UK \\ ${ }^{2}$ Department of Geography and Earth Sciences, University of Malawi 'Chancellor College', Zomba, Malawi \\ ${ }^{3}$ Ministry of Agriculture, Irrigation and Water Development, Government of Malawi, Lilongwe 3, Malawi \\ Email address: \\ laura.kelly.100@strath.ac.uk (L. Kelly), douglas.bertram@strath.ac.uk (D. Bertram), robert.kalin@strath.ac.uk (R. Kalin), \\ cngongondo@cc.ac.mw (C. Ngongondo), hydesibande@yahoo.co.uk (H. Sibande) \\ ${ }^{*}$ Corresponding author
}

\section{To cite this article:}

Laura Kelly, Douglas Bertram, Robert Kalin, Cosmo Ngongondo, Hyde Sibande. A National Scale Assessment of Temporal Variations in Groundwater Discharge to Rivers: Malawi. American Journal of Water Science and Engineering. Special Issue: 21st Century Water Management. Vol. 6, No. 1, 2020, pp. 39-49. doi: 10.11648/j.ajwse.20200601.15

Received: December 14, 2019; Accepted: February 20, 2020; Published: February 28, 2020

\begin{abstract}
This study presents the first national-scale assessment of temporal variations in the Base Flow Index (BFI) for watercourses in Malawi. A proxy indicator of groundwater discharge to rivers, the BFI is a measure of the ratio of long term baseflow to total river flow and is a key parameter for sustainable water resources management. The smoothed minima technique was applied to river flow data from 68 river gauges across Malawi (data records ranging from 11-64 years). The long-term average annual BFI for each gauged site was determined, as well as seasonal values of BFI. The Mann Kendal (MK) statistical test was used to identify trends in the BFI. Average annual BFI was 0.57 , average wet season BFI was 0.52 and average dry season BFI was 0.97 . This indicates that $57 \%, 52 \%$ and $97 \%$ of the total river flow is derived from groundwater and other stored sources in the annual, wet and dry season periods respectively. These results show that baseflow in Malawi follows a seasonal pattern with minimal differences between the average annual and average wet season BFI; however, significant increases are generally seen in the dry season BFI. The results also found long-term behavioural changes in BFI across all periods. Annually, $74 \%$ showed no trend, $10 \%$ showed an increasing trend and $16 \%$ showed a decreasing trend. The wet season trends showed similar values with $66 \%$ showing no trend, $16 \%$ showing an increasing trend and $18 \%$ showing a decreasing trend. In contrast, for the dry season, 93\% showed no trend, $1 \%$ showed an increasing trend and $6 \%$ showed a decreasing trend. The dataset determined in this study can support sustainable water resources management in Malawi and contribute to measuring its progress towards Sustainable Development Goal 6.
\end{abstract}

Keywords: Baseflow, BFI, Groundwater Discharge, Malawi, SDG6

\section{Introduction}

The provision of reliable hydrological data continues to be a challenge for many countries across the globe $[1,2]$. In the developing world context, this is attributed to several factors including insufficient budgets, inability to attract, train and retain qualified staff and declining maintenance of hydrological stations [3]. Where hydrological data does exist, it is often of poor quality, characterized by missing data and is generally sporadic in nature [2, 4]. Irrespective of the challenges, efforts continue to focus on providing reliable data to underpin sustainable water resources management.

One key parameter determined from hydrological data is baseflow. Baseflow is the component of river flow derived from groundwater and other stored sources which may include slow-moving interflow and connected wetlands and lakes [5, 6]. Hydrograph analysis is frequently used to determine baseflow by separating the total river flow in a hydrograph into its fast-moving component (surface runoff) and its slow-moving component (baseflow). Baseflow is commonly expressed as the Base Flow Index (BFI) which is a unitless parameter, ranging from near 0.0 ; indicating a river with a relatively low proportion of baseflow, to close to 1.0 ; 
indicating a river with a high proportion of baseflow $[2,5]$. Baseflow has been traditionally used as a proxy indicator of groundwater discharge $[6,7]$. The determination of baseflow, and in particular its temporal and spatial variations, is increasingly considered to underpin many holistic sustainable water management approaches such as integrated water resource management (IWRM) and conjunctive water use [8, 9]. Specifically, baseflow and BFI data are used in low flow studies [5], environmental flow calculations [10], hydropower generation [11] and as a groundwater availability indicator [12]. Although the provision of baseflow data is pertinent to all countries, it is especially crucial for countries which experience long dry seasons with limited rainfall and where rivers depend on groundwater to sustain flows as a result of the minimal surface runoff.

One example is Malawi in Southern Africa (Figure 1). To date, there have been few studies published on baseflow in the country and those that do exist are limited in their spatial and temporal coverage [12-14]. A summary of the existing work can be found in Kelly et al [2]. Recent studies have sought to promote the importance of baseflow research in Malawi and provide comprehensive coverage of several key catchments. For example, Kelly et al [2] investigated baseflow in the Bua catchment in Central Malawi and quantified annual and seasonal BFI. Generally, the study found minimal difference between the average annual and wet season BFI, however, the dry season BFI was $>0.94$ across all gauges highlighting the importance of baseflow in maintaining dry season flows. This behavioural pattern was also mirrored in a study on baseflow in the Shire River Basin in Southern Malawi which found minimal difference between the annual and wet season BFI, but with the majority of dry season BFIs increasing to $>0.75$ [7]. Further, both studies explored long term trends in the BFI and found mixed results. For example, some stations observed no statistically significant trends, some seen increasing trends and some seen decreasing trends. The variation in trends observed shows how the baseflow and groundwater discharge to the rivers is remaining stable in some catchments but changing over time under the influence of natural and anthropogenic factors in others. There remains a gap in the literature to quantify seasonal and long-term trends in BFI on a national scale in Malawi.

Therefore, the main goal of this study is to present a national-scale assessment of temporal variations in groundwater discharge in Malawi using the BFI approach. Specifically, the objectives were to (1) quantify the annual and seasonal BFI and (2) evaluate long term trends in the BFI across the country. The findings of this study are expected to provide crucial baseline data which will support sustainable water resources management in the country.

\section{Material and Methods}

\subsection{Study Area}

This study focused on Malawi; a country known as "the warm heart of Africa" (Figure 1). It is a landlocked country, bordered by Mozambique to the east, south and west, Zambia to the west, and Tanzania to the north and east. Malawi is divided into 17 Water Resource Areas (WRAs), where each WRA represents one hydrological basin as follows; WRA 1 (Shire), WRA 2 (Lake Chilwa), WRA 3 (South West Lakeshore), WRA 4 (Linthipe), WRA 5 (Bua), WRA 6 (Dwangwa), WRA 7 (South Rukuru/North Rumphi), WRA 8 (North Rukuru), WRA 9 (Songwe/Lufira), WRA 10 (South East Lakeshore), WRA 11 (Lake Chiuta), WRA 12 (Likoma Island), WRA 13 (Chizumulu Island), WRA 14 (Ruo), WRA 15 (Nkhota-Hota Lakeshore), WRA 16 (Nkhota-Bay Lakeshore) and WRA 17 (Karonga Lakeshore) (Figure 1). The catchment area for all WRAs combined is approximately $94,000 \mathrm{~km}^{2}$ which excludes the area of Lake Malawi [15].

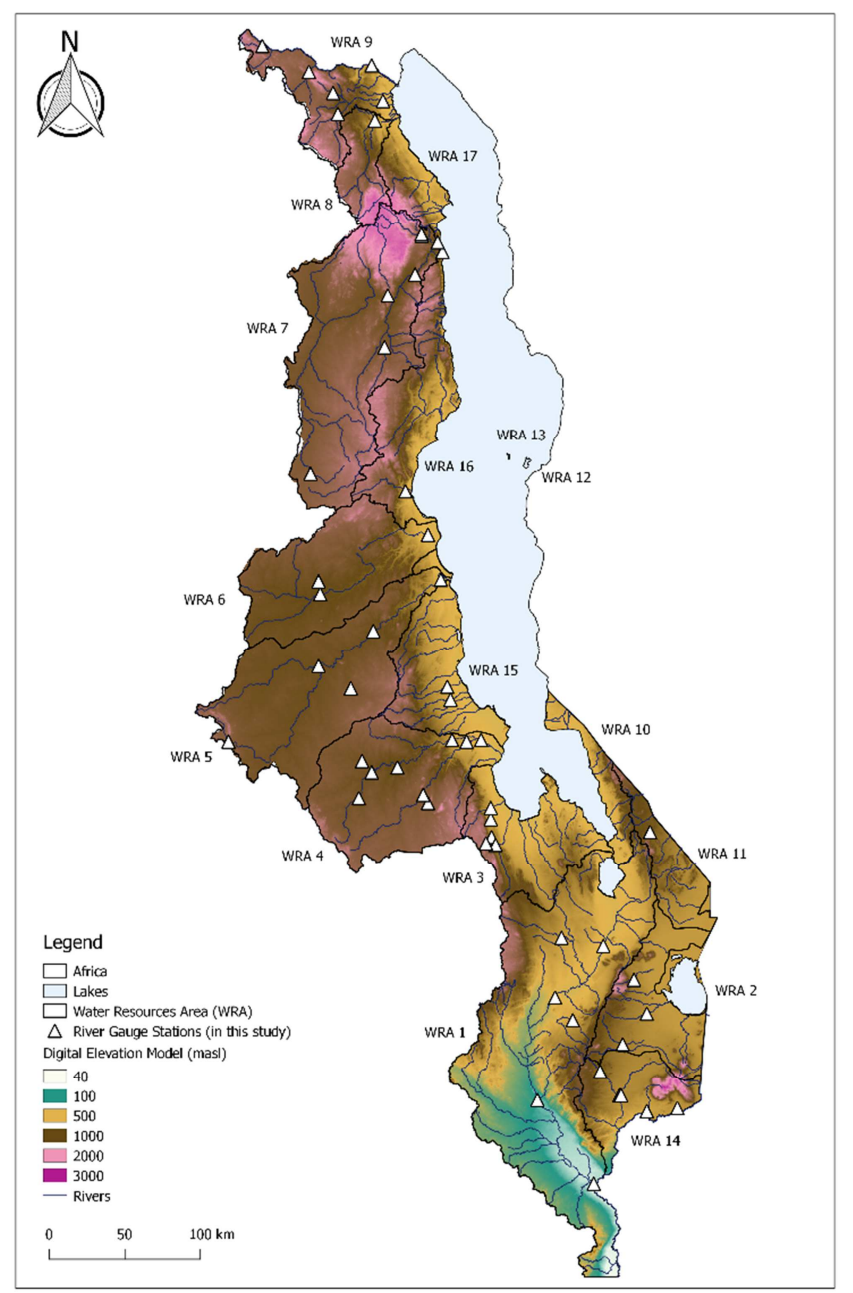

Figure 1. Digital elevation model of Malawi (obtained from the Government of Malawi) with Water Resource Areas, rivers, lakes, and river gauging stations used in this study.

Malawi is covered extensively by surface water bodies. Major rivers in Malawi include the Shire, Bua, Linthipe, Songwe, North Rukuru, South Rukuru, Dwangwa and the Ruo. There are numerous minor tributaries associated with each river. There are four major lakes in Malawi (Lake Chilwa, Lake Chiuta, Lake Malombe and Lake Malawi) with a combined area of approximately $23,855 \mathrm{~km}^{2}$ within the 
Malawian territory [15]. The combined area of the lakes including the Mozambique territory is approximately 29,600 $\mathrm{km}^{2}$ [15]. The most notable lake is Lake Malawi which is a major source of water for lakeshore communities and plays a crucial role in the national tourism, transport, agriculture and fisheries industries [16]. It is the biggest freshwater lake in Malawi, the 3rd biggest in Africa and the 8th biggest in the world. There is only one outflow from Lake Malawi, the Shire River, which is a tributary of the Zambezi in Mozambique. The Shire River supports extensive areas of irrigation together with the water supply to Malawi's second-largest city, Blantyre, and three hydropower schemes which supply approximately $98 \%$ of the national electricity output [16]. Transboundary rivers in Malawi include the Songwe, Ruo and Shire [17]. Despite the number and widespread nature of surface water bodies, the availability and reliability of surface waters are highly variable due to climatology extremes between the wet and the dry season and from year to year [18].

The topography of Malawi is shown in Figure 1. There are four main physiographic zones in the country with varying elevations; the highlands (1,500 to 3,000 masl), the plateau (900 to 1,500 masl), the escarpment and the rift valley floor (500masl at the Lakeshore to about 50masl in the Lower Shire Valley) [18]. The highlands comprise forest vegetation and grassland, the plateau has broad, undulating plains, and grass-covered swampy valleys, and the escarpment is the boundary between the plateau and the rift valley which is a major faulting area. The escarpment is largely protected forests and game reserves, and the rift valley is generally mixed woodland. Malawi is still predominately an agricultural-based society and as such agriculture dominates most of the land use [19]. There are also many designated areas in the form of game reserves, forest reserves and national parks. Wetlands also occur across the country with the most notable being the Elephant marshes in the South.

Malawi's climate is sub-tropical being relatively dry and strongly seasonal. There are two distinct seasons; the wet season and the dry season (1 November-31 April, 1 May-31 October respectively) [15] with $95 \%$ of the annual rainfall occurring in the wet season. The average annual rainfall for Malawi depends on the topographic and climatic conditions and ranges from 700 to $2,400 \mathrm{~mm}$ with a mean annual rainfall of $1,095 \mathrm{~mm}$ [20]. Evaporation in the dry season is only slightly higher than in the wet season. Further information on the climatic characteristics of Malawi can be found in the literature $[21,22]$.

Groundwater is the main source of water supply for the rural populations in Malawi as well as several urban populations. Aquifer types which have been identified in Malawi are alluvial aquifers, sedimentary aquifers and basement aquifers [20]. The basement aquifers underlie at least $80 \%$ of the country and comprise both fractured and weathered aquifers. Detailed geological and hydrogeological maps of Malawi including groundwater occurrences and flow regimes and descriptive texts are available in the Malawi Hydrogeological and Water Quality Atlas 2018 [20]. The atlas was developed by the Ministry of Agriculture, Irrigation and Water Development through the National Water Development Programme and the Shire River Basin Management Programme funded by the World Bank and provide a vital data source.

Water resources management in Malawi is currently carried out by different ministries and institutions, for example, the Ministry for Water Development is primarily responsible for the management of national water resources and the newly formed National Water Resources Authority (NWRA) is responsible for the regulation and promotion of IWRM. Further, regional water boards possess a lower level of responsibility and other stakeholders which also play a role include nonprofit organizations, research institutions and the private sector.

Parameters (i.e. groundwater, river flow) in Malawi are routinely monitored by Government bodies, however, long term continuous datasets are limited due to budgetary constraints [7]. There is no known monitoring of baseflow currently carried out in Malawi, however, it is known to play an important role in several Malawian rivers with dry season flows reported to comprise $90 \%$ baseflow in some river reaches $[2,7]$.

\subsection{Data}

This study focused on data from 68 river gauging stations in Malawi. More gauging stations do exist; however, data could not be obtained. The 68 stations comprised a varied number of stations within each WRA; WRA 1 (9), WRA 2 (3), WRA 3 (5), WRA 4 (9), WRA 5 (6), WRA 6 (3), WRA 7 (10), WRA 8 (1), WRA 9 (7), WRA 11 (2), WRA 14 (6), WRA 15 (2), WRA 16 (3) and WRA 17 (2). Currently, WRA 10,12 and 13 do not have any river gauging stations.

Daily flow rate data were available for each station as shown in Table 1. Data coverage appears varied ranging from 11-64 years with an average of 42 years and it is expected to have missing values throughout. The data was provided by the Surface Water Division of the Department of Water Resources of Malawi.

Figure 1 shows the location of the river gauging stations. For clarity the associated gauge IDs have not been included on the map, instead, the gauges can be viewed via the mWater platform (described in section 2.3) at https://share.mwater.co/v3/console_link/02f661229dbc41ca 9 d038de79f668fd2? share $=a 7 d e 4 a 5 e-48 d c 4245 a b b 595 f 2 d 94 b 9 b$ 75 Co-ordinates could not be obtained for gauges 7E2, 9B5, $11 \mathrm{~A} 6,16 \mathrm{~F} 1,16 \mathrm{~F} 2,17 \mathrm{C} 6$ and $17 \mathrm{C} 10$, and as such are not shown in Figure 1 or the mWater map, however, results are available.

Comprehensive baseflow assessments have previously been completed by Kelly et al for the gauges in WRA 5 [2] and WRA 1 and 14 [7]. Baseflow assessments for the gauges in WRA 3 and WRA 4 have been included in the work of Banda et al [23]. As they form part of the overall national assessment these gauges have been included here for completeness. 
Table 1. Daily flow rate data available for the 68 river gauging stations in Malawi.

\begin{tabular}{|c|c|c|}
\hline Gauge ID & River Name & Data Record \\
\hline 1B1 & Shire & 1948/1949-2011/2012 \\
\hline $1 \mathrm{C} 1$ & Lirangwe & $1951 / 1952-2004 / 2005$ \\
\hline $1 \mathrm{G} 1$ (A) & Shire & $1953 / 1954-2008 / 2009$ \\
\hline $1 \mathrm{~K} 1$ & Mwanza & 1951/1952-1996/1997 \\
\hline $1 \mathrm{~L} 12$ & Shire & $1976 / 1977-2009 / 2010$ \\
\hline $1 \mathrm{M} 1$ & Mkurumadzi & $1980 / 1981-2007 / 2008$ \\
\hline 1P2 & Shire & $1952 / 1953-2004 / 2005$ \\
\hline 1R3 & Rivirivi & $1952 / 1953-2003 / 2004$ \\
\hline $1 \mathrm{~S} 7$ & Nkasi & $1961 / 1962-1996 / 1997$ \\
\hline 2B22 & Thondwe & $1960 / 1961-2006 / 2007$ \\
\hline $2 \mathrm{~B} 33$ & Namadzi & $1961 / 1962-2009 / 2010$ \\
\hline $2 \mathrm{C} 3$ & Domasi & $1958 / 1959-2009 / 2010$ \\
\hline $3 \mathrm{E} 1$ & Nadzipokwe & $1953 / 1954-2009 / 2010$ \\
\hline $3 \mathrm{E} 2$ & Namikokwe & $1957 / 1958-2002 / 2003$ \\
\hline $3 \mathrm{E} 3$ & Livulezi & $1956 / 1957-2007 / 2008$ \\
\hline $3 \mathrm{E} 5$ & Namikokwe & $1957 / 1958-2008 / 2009$ \\
\hline $3 \mathrm{~F} 3$ & Nadzipulu & $1957 / 1958-2003 / 2004$ \\
\hline 4B1 & Linthipe & $1953 / 1954-2008 / 2009$ \\
\hline $4 \mathrm{~B} 3$ & Linthipe & $1957 / 1958-2007 / 2008$ \\
\hline 4B4 & Diamphwe & $1957 / 1958-2009 / 2010$ \\
\hline 4B9 & Linthipe & $1974 / 1975-2009 / 2010$ \\
\hline $4 \mathrm{C} 2$ & Lilongwe & $1957 / 1958-2009 / 2010$ \\
\hline $4 \mathrm{C} 11$ & Nanjiri & $1985 / 1986-2009 / 2010$ \\
\hline 4D4 & Lilongwe & $1953 / 1954-2008 / 2009$ \\
\hline $4 \mathrm{D} 24$ & Lilongwe & 1990/1991-2004/2005 \\
\hline $4 \mathrm{E} 2$ & Lingadzi & $1959 / 1960-2004 / 2005$ \\
\hline $5 \mathrm{C} 1$ & Bua & $1957 / 1958-2008 / 2009$ \\
\hline 5D1 & Bua & $1958 / 1959-2006 / 2007$ \\
\hline $5 \mathrm{D} 2$ & Bua & $1953 / 1954-2004 / 2005$ \\
\hline $5 \mathrm{D} 3$ & Mtiti & $1958 / 1959-2002 / 2003$ \\
\hline $5 \mathrm{E} 6$ & Bua & $1970 / 1971-2007 / 2008$ \\
\hline $5 \mathrm{~F} 1$ & Rusa & $1964 / 1965-2004 / 2005$ \\
\hline $6 \mathrm{C} 1$ & Dwangwa & $1952 / 1953-2009 / 2010$ \\
\hline $6 \mathrm{C} 5$ & Mpasadzi & $1965 / 1966-2000 / 2001$ \\
\hline 6D10 & Dwanga & $1985 / 1986-2009 / 2010$ \\
\hline 7A3 & South Rukura & $1955 / 1956-2007 / 2008$ \\
\hline 7D8 & Lunyangwa & $1952 / 1953-2007 / 2008$ \\
\hline 7E2 & South Rukuru & $1956 / 1957-1997 / 1998$ \\
\hline $7 F 1$ & Runyina & $1955 / 1956-1997 / 1998$ \\
\hline $7 \mathrm{~F} 2$ & South Rumphi & $1956 / 1957-2007 / 2008$ \\
\hline 7G14 & South Rukuru & $1957 / 1958-2006 / 2007$ \\
\hline 7G18 & South Rukuru & $1985 / 1986-2008 / 2009$ \\
\hline 7H1 & North Rumphi & $1955 / 1956-2007 / 2008$ \\
\hline $7 \mathrm{H} 2$ & Kaziwiziwi & $1952 / 1953-2007 / 2008$ \\
\hline $7 \mathrm{H} 3$ & North Rumphi & $1971 / 1972-2006 / 2007$ \\
\hline $8 \mathrm{~A} 5$ & North Rukuru & 1968/1969-2008/2009 \\
\hline 9A2 & Lufira & $1953 / 1954-2009 / 2010$ \\
\hline 9A4 & Lufira & $1958 / 1959-2007 / 2008$ \\
\hline 9A5 & Kalenje & $1970 / 1971-2006 / 2007$ \\
\hline $9 \mathrm{~B} 3$ & Kaseye & $1970 / 1971-2007 / 2008$ \\
\hline 9B5 & Hanga & $1979 / 1980-2003 / 2004$ \\
\hline 9B6 & Songwe & $1981 / 1982-2007 / 2008$ \\
\hline 9B7 & Songwe & 1985/1986-2011/2012 \\
\hline $11 \mathrm{~A} 6$ & Lusangwisi & 1976/1977-1997/1998 \\
\hline $11 \mathrm{~A} 7$ & Masongola & 1976/1977-1997/1998 \\
\hline $14 \mathrm{~A} 2$ & Luchenza & $1954 / 1955-2001 / 2002$ \\
\hline $14 \mathrm{~A} 3$ & Chisombezi & $1962 / 1963-1999 / 2000$ \\
\hline 14B2 & Thuchila & $1951 / 1952-2002 / 2003$ \\
\hline $14 \mathrm{C} 2$ & Ruo & $1953 / 1954-2007 / 2008$ \\
\hline $14 \mathrm{C} 8$ & Lichenya & 1959/1960-2001/2002 \\
\hline 14D1 & Ruo & 1980/1981-1990/1991 \\
\hline $15 \mathrm{~A} 4$ & Chirua & $1970 / 1971-1999 / 2000$ \\
\hline $15 \mathrm{~A} 8$ & Lingadzi & $1960 / 1961-2009 / 2010$ \\
\hline 16E6 & Dwambadzi & $1972 / 1972-2008 / 2009$ \\
\hline
\end{tabular}

\begin{tabular}{lll}
\hline Gauge ID & River Name & Data Record \\
\hline 16F1 & Limphasa & $1970 / 1971-1990 / 1991$ \\
16F2 & Luweya & $1952 / 1953-1993 / 1994$ \\
17C6 & Wovwe & $1969 / 1970-1992 / 1993$ \\
17C10 & Hara & $1974 / 1975-1988 / 1989$ \\
\hline
\end{tabular}

\subsection{Baseflow Separation Approach and Statistical Trend Analysis}

Baseflow separation, which is a type of hydrograph analysis, was used in this study to determine the BFI from the river data. Specifically, the technique used to perform the baseflow separation was the 'smoothed minima' filtering procedure developed by the Institute of Hydrology [24]. The programme chosen to implement this procedure was the BFI programme [5, 25] as recommended in Kelly et al [2] based on various criteria which were chosen to facilitate the exchange of knowledge with the Government of Malawi. The tool is 'automated, easily accessible, free to obtain and operate, requires minimal training to use and is capable of selecting seasonal periods from input data to quantify BFI' [2].

The river data in this study was characterized by missing data throughout and this study followed the steps recommended in Kelly et al [2] to perform the baseflow separation using the BFI programme. The main assumption with baseflow separation is that it assumes that interflow is negligible and that baseflow is derived entirely from groundwater discharge from the aquifer.

The assessment periods selected were annual and seasonal periods defined by months; annual (1st November-31st October), the wet season (1st November-30th April), and the dry season (1st May-31st October). These periods are as used by the Government of Malawi and in recent baseflow studies for Malawi.

As recommended by the World Meteorological Organisation (WMO), the Mann-Kendal (MK) trend test [26, 27] was used to identify statistically significant trends in the BFI data. The statistical programme XLSTAT was used to apply the test [28].

To promote the exchange of knowledge with the Government of Malawi and other stakeholders, the free data management platform 'mWater' was used in this study to share information where possible. Used in over 160 countries, the main goal of mWater is to make data 'sharable and actionable' by digital monitoring [29]. It is currently being promoted as Malawi's preferred online Management Information System (MIS) for analyzing significant volumes of water and sanitation data in Malawi [30]. The Climate Justice Fund (CJF) Water Futures Programme funded by the Scottish Government, is working in partnership with the Malawian Government to develop the MIS for the rural sector and for long term strategic management of the water, sanitation and hygiene (WASH) sector infrastructure in Malawi [31]. The tool is building a complete assess register of water infrastructure to support the Government achieve Sustainable Development Goal 6 to 'ensure availability and sustainable management of water and sanitation for all. 
mWater data is actively being used in several ongoing research areas including the management of rural groundwater supply [32], the impact of stranded assets for rural water supply [31] and the design of groundwater-quality monitoring networks [33]. As such, an opportunity was seen to initiate the inclusion of baseflow. Further details on the design and development of the mWater MIS in Malawi are provided in Miller et al [30].

\section{Results and Discussion}

\subsection{Average Annual and Seasonal BFI for River Gauging Stations Across Malawi}

The long-term average annual and seasonal (wet and dry) BFI values for the 68 gauging stations across Malawi are
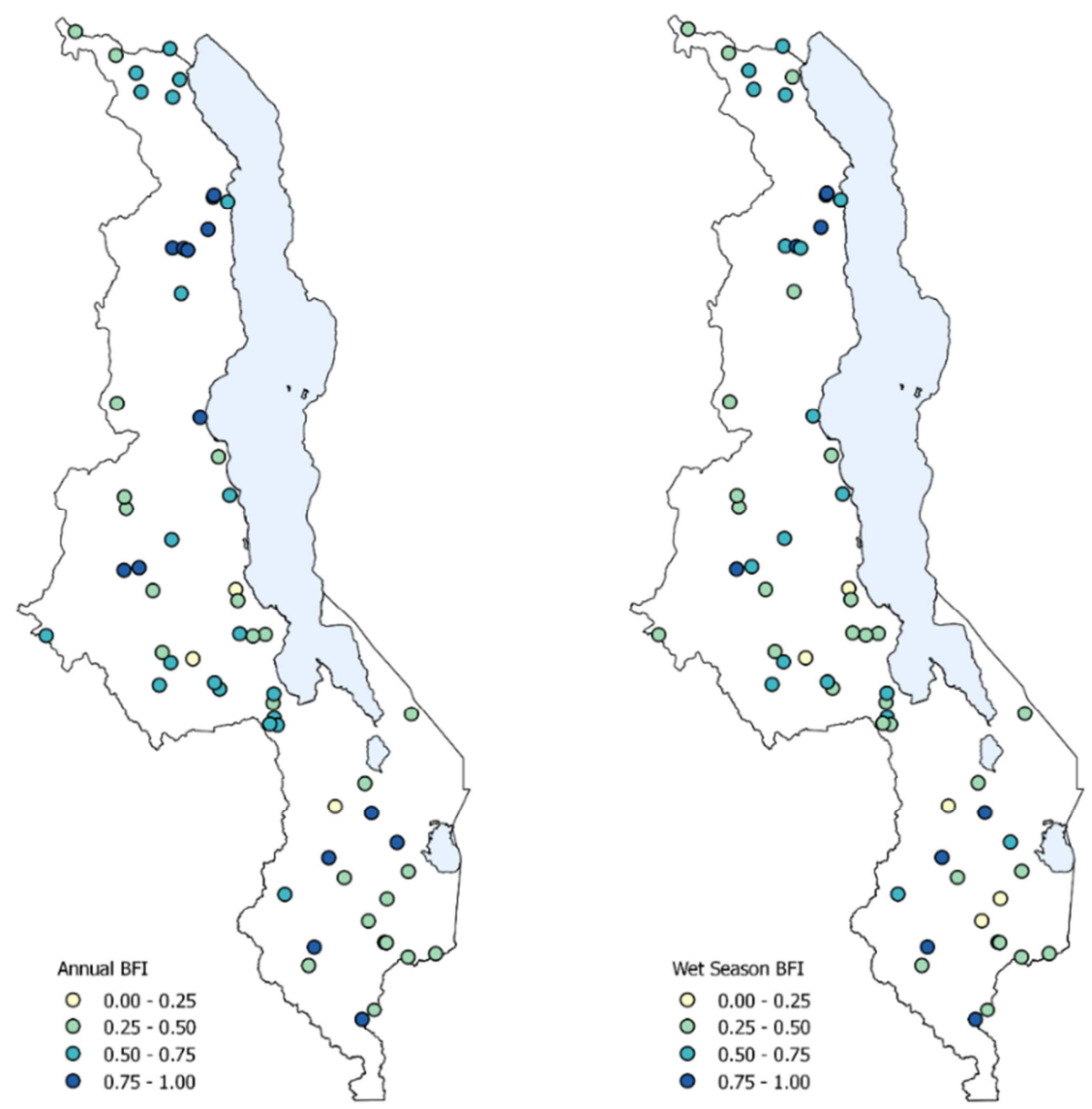

shown in Figure 2 and Table 2. The results have also been shared on the mWater platform and can be accessed at

https://share.mwater.co/v3/console_link/02f661229dbc41c a9d038de79f668fd2? share=a7de4a5e48dc4245abb595f2d94b $9 \mathrm{~b} 75$ The results show that baseflow varies spatially and temporally across Malawi. For example, the results found an average annual BFI for Malawi of 0.57 , an average wet season BFI of 0.52 and an average dry season BFI of 0.97 . This indicates that on average, $57 \%, 52 \%$ and $97 \%$ of the total river flow across Malawi is derived from baseflow from groundwater for the annual, wet and dry season respectively. From this, we can generalize that baseflow behaviour across Malawi follows a distinct seasonal pattern characterized by minimal difference between the annual and wet season baseflow, but with a significant increase in the dry season.

Figure 1. Long term average BFI values in Malawi derived for the annual, wet season and dry season period (graphical).

Table 2. Long term average BFI values in Malawi derived for the annual, wet season and dry season period (tabular).

\begin{tabular}{|c|c|c|c|c|c|c|c|c|c|c|c|}
\hline \multirow{2}{*}{$\begin{array}{l}\text { Gauge } \\
\text { ID }\end{array}$} & \multirow{2}{*}{ River Name } & \multirow{2}{*}{ Data Record } & \multicolumn{3}{|c|}{ ANNUAL BFI } & \multicolumn{3}{|c|}{ WET SEASON BFI } & \multicolumn{3}{|c|}{ DRY SEASON BFI } \\
\hline & & & Average & Min & Max & Average & Min & Max & Average & Min & Max \\
\hline 1B1 & Shire & $1948 / 1949-2011 / 2012$ & 0.97 & 0.78 & 0.99 & 0.95 & 0.08 & 1.00 & 0.98 & 0.85 & 1.00 \\
\hline $1 \mathrm{C} 1$ & Lirangwe & $1951 / 1952-2004 / 2005$ & 0.48 & 0.07 & 0.94 & 0.44 & 0.07 & 0.99 & 0.85 & 0.00 & 0.99 \\
\hline $1 \mathrm{G} 1$ (A) & Shire & $1953 / 1954-2008 / 2009$ & 0.95 & 0.88 & 0.98 & 0.93 & 0.83 & 0.97 & 0.98 & 0.90 & 1.00 \\
\hline $1 \mathrm{~K} 1$ & Mwanza & $1951 / 1952-1996 / 1997$ & 0.38 & 0.05 & 0.76 & 0.33 & 0.04 & 0.73 & 0.76 & 0.24 & 1.00 \\
\hline 1L12 & Shire & $1976 / 1977-2009 / 2010$ & 0.92 & 0.84 & 0.98 & 0.91 & 0.79 & 0.97 & 0.96 & 0.88 & 1.00 \\
\hline $1 \mathrm{M} 1$ & Mkurumadzi & $1980 / 1981-2007 / 2008$ & 0.64 & 0.41 & 0.89 & 0.52 & 0.29 & 0.84 & 0.87 & 0.49 & 0.99 \\
\hline $1 \mathrm{P} 2$ & Shire & $1952 / 1953-2004 / 2005$ & 0.90 & 0.00 & 1.00 & 0.87 & 0.00 & 0.99 & 0.93 & 0.00 & 1.00 \\
\hline 1R3 & Rivirivi & $1952 / 1953-2003 / 2004$ & 0.19 & 0.05 & 0.45 & 0.16 & 0.03 & 0.39 & 0.87 & 0.51 & 0.96 \\
\hline $1 \mathrm{~S} 7$ & Nkasi & $1961 / 1962-1996 / 1997$ & 0.32 & 0.00 & 0.88 & 0.28 & 0.00 & 0.80 & 0.76 & 0.00 & 0.98 \\
\hline 2B22 & Thondwe & $1960 / 1961-2006 / 2007$ & 0.36 & 0.17 & 0.64 & 0.31 & 0.14 & 0.53 & 0.79 & 0.00 & 0.95 \\
\hline
\end{tabular}




\begin{tabular}{|c|c|c|c|c|c|c|c|c|c|c|c|}
\hline \multirow{2}{*}{$\begin{array}{l}\text { Gauge } \\
\text { ID }\end{array}$} & \multirow{2}{*}{ River Name } & \multirow{2}{*}{ Data Record } & \multicolumn{3}{|c|}{ ANNUAL BFI } & \multicolumn{3}{|c|}{ WET SEASON BFI } & \multicolumn{3}{|c|}{ DRY SEASON BFI } \\
\hline & & & Average & Min & Max & Average & Min & Max & Average & Min & Max \\
\hline 2B33 & Namadzi & $1961 / 1962-2009 / 2010$ & 0.27 & 0.04 & 0.63 & 0.22 & 0.03 & 0.53 & 0.79 & 0.00 & 0.98 \\
\hline $2 \mathrm{C} 3$ & Domasi & $1958 / 1959-2009 / 2010$ & 0.76 & 0.57 & 0.87 & 0.72 & 0.49 & 0.85 & 0.93 & 0.80 & 0.98 \\
\hline $3 \mathrm{E} 1$ & Nadzipokwe & $1953 / 1954-2009 / 2010$ & 0.49 & 0.15 & 0.78 & 0.42 & 0.00 & 0.72 & 0.94 & 0.59 & 0.98 \\
\hline $3 \mathrm{E} 2$ & Namikokwe & $1957 / 1958-2002 / 2003$ & 0.56 & 0.00 & 0.78 & 0.58 & 0.34 & 0.98 & 0.86 & 0.00 & 0.98 \\
\hline $3 \mathrm{E} 3$ & Livulezi & $1956 / 1957-2007 / 2008$ & 0.54 & 0.22 & 0.98 & 0.43 & 0.16 & 0.65 & 0.90 & 0.41 & 0.98 \\
\hline $3 \mathrm{E} 5$ & Namikokwe & $1957 / 1958-2008 / 2009$ & 0.55 & 0.00 & 0.85 & 0.50 & 0.00 & 0.88 & 0.95 & 0.88 & 0.99 \\
\hline $3 \mathrm{~F} 3$ & Nadzipulu & $1957 / 1958-2003 / 2004$ & 0.72 & 0.55 & 0.84 & 0.64 & 0.33 & 0.79 & 0.93 & 0.64 & 0.99 \\
\hline 4B1 & Linthipe & $1953 / 1954-2008 / 2009$ & 0.43 & 0.16 & 0.65 & 0.39 & 0.10 & 0.64 & 0.78 & 0.10 & 0.99 \\
\hline 4B3 & Linthipe & $1957 / 1958-2007 / 2008$ & 0.52 & 0.03 & 0.90 & 0.48 & 0.03 & 0.91 & 0.89 & 0.62 & 0.98 \\
\hline 4B4 & Diamphwe & $1957 / 1958-2009 / 2010$ & 0.63 & 0.27 & 0.92 & 0.58 & 0.23 & 0.93 & 0.88 & 0.60 & 0.99 \\
\hline 4B9 & Linthipe & $1974 / 1975-2009 / 2010$ & 0.37 & 0.00 & 0.56 & 0.36 & 0.14 & 0.52 & 0.77 & 0.00 & 0.96 \\
\hline $4 \mathrm{C} 2$ & Lilongwe & 1957/1958-2009/2010 & 0.51 & 0.00 & 0.77 & 0.42 & 0.00 & 0.65 & 0.91 & 0.65 & 0.99 \\
\hline $4 \mathrm{C} 11$ & Nanjiri & 1985/1986-2009/2010 & 0.21 & 0.04 & 0.42 & 0.17 & 0.04 & 0.42 & 0.75 & 0.56 & 0.98 \\
\hline 4D4 & Lilongwe & $1953 / 1954-2008 / 2009$ & 0.65 & 0.47 & 0.76 & 0.59 & 0.41 & 0.71 & 0.92 & 0.72 & 0.98 \\
\hline 4D24 & Lilongwe & $1990 / 1991-2004 / 2005$ & 0.70 & 0.52 & 0.89 & 0.67 & 0.49 & 0.90 & 0.87 & 0.80 & 0.95 \\
\hline 4E2 & Lingadzi & $1959 / 1960-2004 / 2005$ & 0.37 & 0.06 & 0.93 & 0.37 & 0.05 & 0.93 & 0.80 & 0.21 & 0.99 \\
\hline $5 \mathrm{C} 1$ & Bua & $1957 / 1958-2008 / 2009$ & 0.74 & 0.43 & 0.94 & 0.69 & 0.40 & 0.90 & 0.94 & 0.81 & 0.99 \\
\hline 5D1 & Bua & 1958/1959-2006/2007 & 0.75 & 0.43 & 0.94 & 0.74 & 0.41 & 0.93 & 0.93 & 0.55 & 1.00 \\
\hline 5D2 & Bua & $1953 / 1954-2004 / 2005$ & 0.76 & 0.11 & 0.98 & 0.74 & 0.11 & 0.98 & 0.84 & 0.00 & 1.00 \\
\hline $5 \mathrm{D} 3$ & Mtiti & $1958 / 1959-2002 / 2003$ & 0.48 & 0.05 & 0.84 & 0.45 & 0.05 & 0.77 & 0.84 & 0.00 & 1.00 \\
\hline $5 \mathrm{E} 6$ & Bua & 1970/1971-2007/2008 & 0.54 & 0.37 & 0.70 & 0.46 & 0.25 & 0.90 & 0.90 & 0.47 & 0.98 \\
\hline $5 \mathrm{~F} 1$ & Rusa & $1964 / 1965-2004 / 2005$ & 0.80 & 0.26 & 0.98 & 0.79 & 0.24 & 0.95 & 0.89 & 0.61 & 1.00 \\
\hline $6 \mathrm{C} 1$ & Dwangwa & $1952 / 1953-2009 / 2010$ & 0.28 & 0.07 & 1.00 & 0.28 & 0.06 & 1.00 & 0.82 & 0.10 & 1.00 \\
\hline $6 \mathrm{C} 5$ & Mpasadzi & $1965 / 1966-2000 / 2001$ & 0.47 & 0.20 & 0.87 & 0.43 & 0.17 & 0.87 & 0.74 & 0.04 & 1.00 \\
\hline 6D10 & Dwanga & 1985/1986-2009/2010 & 0.35 & 0.00 & 0.68 & 0.38 & 0.00 & 0.64 & 0.71 & 0.00 & 0.98 \\
\hline 7A3 & South Rukura & $1955 / 1956-2007 / 2008$ & 0.35 & 0.00 & 0.84 & 0.35 & 0.00 & 0.79 & 0.73 & 0.00 & 1.00 \\
\hline 7D8 & Lunyangwa & $1952 / 1953-2007 / 2008$ & 0.53 & 0.21 & 0.73 & 0.41 & 0.01 & 0.69 & 0.84 & 0.58 & 0.96 \\
\hline 7E2 & South Rukuru & 1956/1957-1997/1998 & 0.71 & 0.31 & 0.86 & 0.71 & 0.29 & 0.94 & 0.87 & 0.67 & 0.99 \\
\hline $7 \mathrm{~F} 1$ & Runyina & 1955/1956-1997/1998 & 0.80 & 0.52 & 0.91 & 0.72 & 0.28 & 0.85 & 0.96 & 0.85 & 0.99 \\
\hline $7 \mathrm{~F} 2$ & South Rumphi & $1956 / 1957-2007 / 2008$ & 0.85 & 0.71 & 0.90 & 0.77 & 0.61 & 0.86 & 0.97 & 0.88 & 0.99 \\
\hline $7 \mathrm{G} 14$ & South Rukuru & $1957 / 1958-2006 / 2007$ & 0.80 & 0.00 & 0.93 & 0.76 & 0.00 & 0.93 & 0.97 & 0.90 & 0.99 \\
\hline 7G18 & South Rukuru & $1985 / 1986-2008 / 2009$ & 0.84 & 0.73 & 0.92 & 0.75 & 0.00 & 0.90 & 0.97 & 0.87 & 0.99 \\
\hline 7H1 & North Rumphi & $1955 / 1956-2007 / 2008$ & 0.84 & 0.00 & 0.91 & 0.78 & 0.00 & 0.95 & 0.98 & 0.94 & 0.99 \\
\hline $7 \mathrm{H} 2$ & Kaziwiziwi & $1952 / 1953-2007 / 2008$ & 0.87 & 0.76 & 0.92 & 0.79 & 0.64 & 0.98 & 0.96 & 0.74 & 0.99 \\
\hline $7 \mathrm{H3}$ & North Rumphi & 1971/1972-2006/2007 & 0.71 & 0.29 & 0.83 & 0.60 & 0.20 & 0.75 & 0.93 & 0.79 & 0.98 \\
\hline $8 \mathrm{~A} 5$ & North Rukuru & $1968 / 1969-2008 / 2009$ & 0.60 & 0.00 & 0.83 & 0.55 & 0.00 & 1.00 & 0.91 & 0.52 & 1.00 \\
\hline 9A2 & Lufira & $1953 / 1954-2009 / 2010$ & 0.54 & 0.00 & 0.75 & 0.48 & 0.00 & 0.73 & 0.92 & 0.54 & 0.99 \\
\hline 9A4 & Lufira & $1958 / 1959-2007 / 2008$ & 0.71 & 0.44 & 0.94 & 0.62 & 0.33 & 0.94 & 0.92 & 0.46 & 0.99 \\
\hline 9A5 & Kalenje & $1970 / 1971-2006 / 2007$ & 0.63 & 0.00 & 0.79 & 0.53 & 0.00 & 0.81 & 0.92 & 0.82 & 0.98 \\
\hline 9B3 & Kaseye & $1970 / 1971-2007 / 2008$ & 0.33 & 0.15 & 0.56 & 0.32 & 0.13 & 0.53 & 0.78 & 0.03 & 0.98 \\
\hline 9B5 & Hanga & 1979/1980-2003/2004 & 0.25 & 0.07 & 0.53 & 0.21 & 0.00 & 0.43 & 0.70 & 0.00 & 0.95 \\
\hline 9B6 & Songwe & $1981 / 1982-2007 / 2008$ & 0.50 & 0.30 & 0.72 & 0.44 & 0.14 & 0.90 & 0.94 & 0.8 & 0.99 \\
\hline 9B7 & Songwe & 1985/1986-2011/2012 & 0.64 & 0.53 & 0.77 & 0.56 & 0.45 & 0.71 & 0.86 & 0.53 & 0.98 \\
\hline $11 \mathrm{~A} 6$ & Lusangwisi & 1976/1977-1997/1998 & 0.44 & 0.21 & 0.74 & 0.36 & 0.12 & 0.66 & 0.87 & 0.33 & 0.98 \\
\hline $11 \mathrm{~A} 7$ & Masongola & 1976/1977-1997/1998 & 0.45 & 0.27 & 0.75 & 0.36 & 0.21 & 0.68 & 0.90 & 0.56 & 0.97 \\
\hline $14 \mathrm{~A} 2$ & Luchenza & $1954 / 1955-2001 / 2002$ & 0.43 & 0.07 & 0.78 & 0.37 & 0.06 & 0.68 & 0.87 & 0.62 & 0.97 \\
\hline $14 \mathrm{~A} 3$ & Chisombezi & 1962/1963-1999/2000 & 0.27 & 0.10 & 0.54 & 0.23 & 0.00 & 0.89 & 0.81 & 0.13 & 0.97 \\
\hline 14B2 & Thuchila & $1951 / 1952-2002 / 2003$ & 0.36 & 0.12 & 0.58 & 0.34 & 0.12 & 0.56 & 0.74 & 0.00 & 0.97 \\
\hline $14 C 2$ & Ruo & $1953 / 1954-2007 / 2008$ & 0.46 & 0.20 & 0.69 & 0.47 & 0.17 & 0.67 & 0.49 & 0.15 & 0.75 \\
\hline $14 C 8$ & Lichenya & $1959 / 1960-2001 / 2002$ & 0.40 & 0.20 & 0.59 & 0.37 & 0.14 & 0.58 & 0.53 & 0.12 & 0.79 \\
\hline 14D1 & Ruo & 1980/1981-1990/1991 & 0.43 & 0.31 & 0.48 & 0.36 & 0.26 & 0.43 & 0.70 & 0.51 & 0.79 \\
\hline $15 \mathrm{~A} 4$ & Chirua & 1970/1971-1999/2000 & 0.17 & 0.00 & 0.58 & 0.18 & 0.00 & 0.94 & 0.72 & 0.00 & 0.99 \\
\hline $15 \mathrm{~A} 8$ & Lingadzi & $1960 / 1961-2009 / 2010$ & 0.49 & 0.07 & 0.94 & 0.42 & 0.06 & 0.91 & 0.95 & 0.70 & 0.99 \\
\hline 16E6 & Dwambadzi & $1972 / 1972-2008 / 2009$ & 0.78 & 0.30 & 0.93 & 0.71 & 0.22 & 0.98 & 0.91 & 0.12 & 0.99 \\
\hline $16 \mathrm{~F} 1$ & Limphasa & 1970/1971-1990/1991 & 0.67 & 0.57 & 0.82 & 0.56 & 0.42 & 0.75 & 0.86 & 0.67 & 0.97 \\
\hline $16 \mathrm{~F} 2$ & Luweya & 1952/1953-1993/1994 & 0.76 & 0.55 & 0.90 & 0.69 & 0.43 & 0.94 & 0.90 & 0.75 & 0.98 \\
\hline $17 \mathrm{C} 6$ & Wovwe & 1969/1970-1992/1993 & 0.85 & 0.57 & 0.95 & 0.80 & 0.46 & 0.94 & 0.93 & 0.71 & 0.98 \\
\hline $17 \mathrm{C} 10$ & Hara & 1974/1975-1988/1989 & 0.70 & 0.53 & 0.84 & 0.55 & 0.35 & 0.77 & 0.91 & 0.68 & 0.99 \\
\hline
\end{tabular}

Such a broad generalization of baseflow, although useful, is often limited in application. The BFI results display considerable variability within the annual and wet season BFI in all gauges, as shown by the minimum and maximum BFIs Table 2. The minimum and maximum averages found were 0.17-0.97 (annual), 0.16-0.95 (wet season) and 0.49-0.98 (dry season). These variations highlight the dynamic nature of baseflow and how it changes under the influence of natural and anthropogenic factors. As the baseflow is derived from groundwater discharge from the local aquifers, this dynamic behaviour is also reflected back to the groundwater pattern. 


\subsection{Long Term Trends in BFI for Gauging Stations Across Malawi}

This study presents the first national dataset on detecting long term trends in BFI in Malawi. The MK test was used to identify statistically significant trends in the BFI results and the results are presented in Figure 3 and Table 3.

The results provide evidence of long-term behavioural changes in baseflow in Malawi over the assessment periods. The trends in BFI vary spatially across the country and temporarily through time. Annually, of the 68 gauging stations assessed, and in terms of statistically significant trends, $74 \%$ showed no trend, $10 \%$ showed an increasing trend and $16 \%$ showed a decreasing trend. The wet season trends showed similar values with $66 \%$ showing no trend, $16 \%$ showing an increasing trend and 18\% showing a decreasing trend. In contrast, for the dry season, 93\% showed no trend, $1 \%$ showed an increasing trend and $6 \%$ showed a decreasing trend (Figure 3 ).

No trend indicates that the baseflow component of these rivers has remained stable over time, and as suggested by Kelly et al [7] that these catchments are well managed with minimal impacts from anthropogenic activities. Groundwater storage in the area is expected to be unaffected by over abstractions from boreholes. This is the case for most of the river gauging stations during the annual (74\%), wet season $(66 \%)$ and dry season $(93 \%)$.

Increasing trends are evident across the annual (10\%), the wet season (16\%) and the dry season (1\%). Increasing trends in BFI could be attributed to increases in the local groundwater table due to increased rainfall and recharge in the area which can be considered positive in terms of sustainable water resources management. On the other hand, increasing trends in BFI could also suggest a decreasing trend in rainfall intensity in the area which would result in reduced surface runoff available for the river. In addition, conservations efforts may also be having an impact in some areas. For example, the Ruo River (14C2) shows increasing BFI trends across all assessment periods. This catchment is occupied with numerous tea estates in the lower part and evergreen forests and few settlements in the upper part. There have been relentless efforts to conserve the Mulanje Mountain by various stakeholders especially the Mulanje Mountain Conservation Trust. These increasing trends in BFI suggest that these efforts are having a positive impact.

In contrast, decreasing trends in baseflow suggest that the local groundwater table is declining, perhaps under the impact of climate change or over-abstraction of groundwater. Decreasing trends are evident across the annual (16\%), the wet season $(18 \%)$ and the dry season $(6 \%)$. Declines in baseflow and groundwater levels can serve as a warning sign that practices in the catchment may not be sustainable and should be investigated further. Where the decline in baseflow continues over time, ultimately the river will become disconnected from the feeding aquifer and the river will cease to flow in the dry season [34].

Interestingly, decreasing trends in BFI were found in the wet season when it is presumed that there is minimal threat to groundwater levels because rainfall generates surface runoff to the rivers. This indicates that groundwater is being unsustainably abstracted in these areas in the wet season and impacting the groundwater levels. Decreasing trends in the Northern and Central regions of Malawi is of concern as Lake Malawi depends greatly on the inflows from many of these river catchments, especially in the dry season where aquifers maintain baseflows to the main rivers. If the volume of baseflow in these rivers was reduced, it would negatively impact the lake levels and in turn, the flow available for the Shire river would also be impacted.

Establishing the relationship between groundwater and rivers is still in its infancy in Malawi; however, this study adds to existing knowledge and provides new insight into groundwater discharge as baseflow to rivers across the country. The results represent a comprehensive national dataset on baseflow for Malawi which will be of interest to the Malawian Government who continues to work towards sustainable management and development of their country's water resources. For example, they may include these results in catchment management plans, in hydrological assessment requiring $\mathrm{BFI}$, as a guide for proposed new developments on a river and to identify new lines of research as mentioned in the previous paragraph. The BFI results show how wet season and dry season BFI can vary significantly from annual values. As such, the seasonal BFI results may be considered in the country's current National Irrigation Plan where design calculations appear to have focused on annual BFI values [35]. Identification and understanding of why these changes are occurring are fundamental in ensuring that further degradation of the rivers does not occur and providing protection for the rivers who currently exhibit no changes. It was outside the scope of this study to evaluate trends in factors which influence baseflow behaviour, for example, rainfall, over-abstraction of groundwater and deforestation. Further research should aim to quantify the magnitude of these trends and evaluate these influencing factors.

Finally, the Malawian Government may also use the results as a means of providing an initial dataset for Sustainable Development Goal, Target 6.6 'By 2020, protect and restore water-related ecosystems, including mountains, forests, wetlands, rivers, aquifers and lakes' [36]. This target is tracked by indicator 6.1.1 which partly calls for data for quantifying 'changes over time in the quantity of water in ecosystems (rivers, lakes and groundwater). With 2020 upon us, there is currently no data associated with this indicator on a global scale [37], however, with the results of this study, Malawi can make its contribution and further evaluation of its progress towards the goal. 


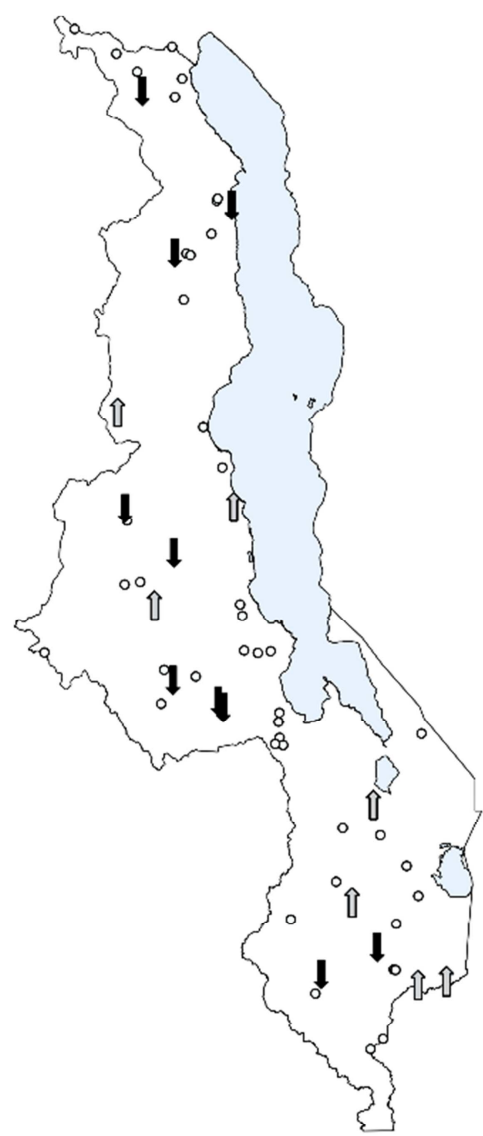

Annual BFI Trends

- No Statistically Significant Trend (74\%)

亿 Statistically Significant 'Increasing' Trend (10\%)

$\downarrow$ Statistically Significant 'Decreasing' Trend (16\%)

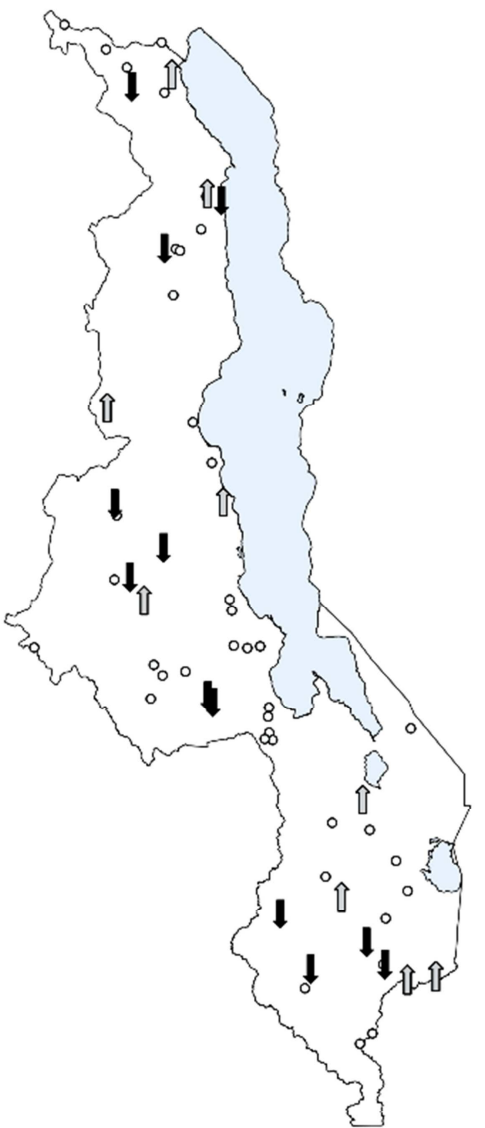

Wet Season BFI Trends

- No Statistically Significant Trend (66\%)

if Statistically Significant 'Increasing' Trend (16\%)

$\downarrow$ Statistically Significant 'Decreasing' Trend (18\%)

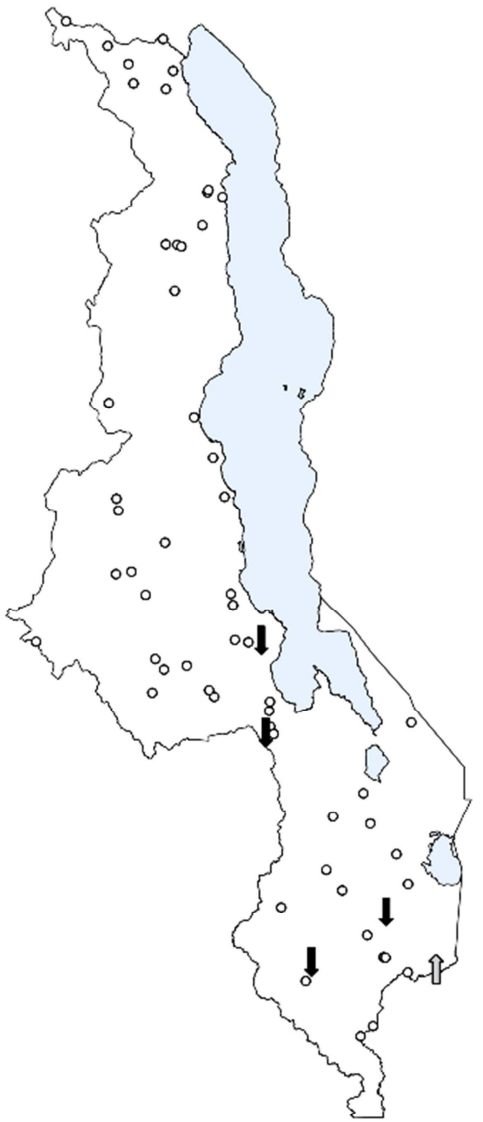

Dry Season BFI Trends

- No Statistically Significant Trend ( $93 \%)$

If Statistically Significant 'Increasing' Trend (1\%)

\Statistically Significant 'Decreasing' Trend (6\%)

Figure 2. Mann Kendall statistical results for average annual and seasonal BFI for the 68 gauges in Malawi (trend at 1\% significance) (graphical).

Table 3. Mann Kendall statistical results for average annual and seasonal BFI for the 68 gauges in Malawi (trend at 1\% significance) (tabular).

\begin{tabular}{|c|c|c|c|c|c|}
\hline Gauge ID & River Name & Data Record & ANNUAL TREND & WET SEASON TREND & DRY SEASON TREND \\
\hline 1B1 & Shire & $1948 / 1949-2011 / 2012$ & 0 & o & o \\
\hline $1 \mathrm{C} 1$ & Lirangwe & $1951 / 1952-2004 / 2005$ & $\uparrow$ & $\uparrow$ & ○ \\
\hline $1 \mathrm{G} 1$ (A) & Shire & $1953 / 1954-2008 / 2009$ & $\circ$ & ○ & ० \\
\hline $1 \mathrm{~K} 1$ & Mwanza & $1951 / 1952-1996 / 1997$ & $\circ$ & $\circ$ & ० \\
\hline $1 \mathrm{~L} 12$ & Shire & $1976 / 1977-2009 / 2010$ & $\downarrow$ & $\downarrow$ & $\downarrow$ \\
\hline $1 \mathrm{M} 1$ & Mkurumadzi & $1980 / 1981-2007 / 2008$ & ० & $\downarrow$ & ○ \\
\hline $1 \mathrm{P} 2$ & Shire & $1952 / 1953-2004 / 2005$ & $\circ$ & $\circ$ & ○ \\
\hline $1 \mathrm{~S} 7$ & Nkasi & $1961 / 1962-1996 / 1997$ & $\uparrow$ & $\uparrow$ & ○ \\
\hline $2 \mathrm{~B} 22$ & Thondwe & $1960 / 1961-2006 / 2007$ & $\circ$ & $\circ$ & ○ \\
\hline $2 \mathrm{~B} 33$ & Namadzi & $1961 / 1962-2009 / 2010$ & $\circ$ & $\circ$ & $\downarrow$ \\
\hline $2 \mathrm{C} 3$ & Domasi & $1958 / 1959-2009 / 2010$ & $\circ$ & $\circ$ & 0 \\
\hline $3 \mathrm{E} 1$ & Nadzipokwe & $1953 / 1954-2009 / 2010$ & $\circ$ & ○ & ○ \\
\hline $3 \mathrm{E} 2$ & Namikokwe & $1957 / 1958-2002 / 2003$ & $\circ$ & $\circ$ & o \\
\hline $3 \mathrm{E} 3$ & Livulezi & $1956 / 1957-2007 / 2008$ & $\circ$ & $\circ$ & ○ \\
\hline $4 \mathrm{~B} 1$ & Linthipe & $1953 / 1954-008 / 2009$ & $\circ$ & $\circ$ & $\downarrow$ \\
\hline $4 \mathrm{~B} 3$ & Linthipe & $1957 / 1958-2007 / 2008$ & $\downarrow$ & $\downarrow$ & ० \\
\hline 4B4 & Diamphwe & $1957 / 1958-2009 / 2010$ & $\downarrow$ & $\downarrow$ & ० \\
\hline $4 \mathrm{~B} 9$ & Linthipe & $1974 / 1975-2009 / 2010$ & $\circ$ & ० & ० \\
\hline $4 \mathrm{C} 2$ & Lilongwe & $1957 / 1958-2009 / 2010$ & $\circ$ & $\circ$ & ○ \\
\hline $4 \mathrm{C} 11$ & Nanjiri & $1985 / 1986-2009 / 2010$ & $\circ$ & ○ & ० \\
\hline 4D4 & Lilongwe & $1953 / 1954-2008 / 2009$ & $\downarrow$ & $\circ$ & ○ \\
\hline 4D24 & Lilongwe & $1990 / 1991-2004 / 2005$ & $\circ$ & $\circ$ & ○ \\
\hline
\end{tabular}




\begin{tabular}{|c|c|c|c|c|c|}
\hline Gauge ID & River Name & Data Record & ANNUAL TREND & WET SEASON TREND & DRY SEASON TREND \\
\hline $4 \mathrm{E} 2$ & Lingadzi & $1959 / 1960-2004 / 2005$ & 0 & 0 & 0 \\
\hline $5 \mathrm{C} 1$ & Bua & $1957 / 1958-2008 / 2009$ & $\uparrow$ & $\uparrow$ & $\circ$ \\
\hline $5 \mathrm{D} 1$ & Bua & $1958 / 1959-2006 / 2007$ & $\downarrow$ & $\downarrow$ & $\circ$ \\
\hline 5D2 & Bua & $1953 / 1954-2004 / 2005$ & 0 & $\downarrow$ & o \\
\hline $5 \mathrm{D} 3$ & Mtiti & $1958 / 1959-2002 / 2003$ & $\uparrow$ & $\uparrow$ & $\circ$ \\
\hline $5 \mathrm{E} 6$ & Bua & $1970 / 1971-2007 / 2008$ & o & $\circ$ & $\circ$ \\
\hline $5 \mathrm{~F} 1$ & Rusa & $1964 / 1965-2004 / 2005$ & $\circ$ & $\circ$ & $\circ$ \\
\hline $6 \mathrm{C} 1$ & Dwangwa & $1952 / 1953-2009 / 2010$ & o & o & o \\
\hline $6 \mathrm{C} 5$ & Mpasadzi & $1965 / 1966-2000 / 2001$ & $\downarrow$ & $\downarrow$ & ० \\
\hline $6 \mathrm{D} 10$ & Dwanga & $1985 / 1986-2009 / 2010$ & $\circ$ & ○ & $\circ$ \\
\hline 7A3 & South Rukura & $1955 / 1956-2007 / 2008$ & $\uparrow$ & $\uparrow$ & $\circ$ \\
\hline 7D8 & Lunyangwa & $1952 / 1953-2007 / 2008$ & $\circ$ & ○ & ○ \\
\hline 7E2 & South Rukuru & 1956/1957-1997/1998 & $\circ$ & $\circ$ & $\circ$ \\
\hline $7 F 1$ & Runyina & 1955/1956-1997/1998 & $\downarrow$ & $\downarrow$ & $\circ$ \\
\hline $7 F 2$ & South Rumphi & $1956 / 1957-2007 / 2008$ & $\circ$ & $\circ$ & $\circ$ \\
\hline 7G14 & South Rukuru & $1957 / 1958-2006 / 2007$ & $\circ$ & $\circ$ & $\circ$ \\
\hline $7 \mathrm{G} 18$ & South Rukuru & $1985 / 1986-2008 / 2009$ & $\circ$ & $\circ$ & $\circ$ \\
\hline $7 \mathrm{H} 1$ & North Rumphi & $1955 / 1956-2007 / 2008$ & $\circ$ & $\circ$ & ० \\
\hline $7 \mathrm{H} 2$ & Kaziwiziwi & $1952 / 1953-2007 / 2008$ & $\circ$ & $\uparrow$ & $\circ$ \\
\hline $7 \mathrm{H} 3$ & North Rumphi & $1971 / 1972-2006 / 2007$ & $\downarrow$ & $\downarrow$ & $\circ$ \\
\hline $8 \mathrm{~A} 5$ & North Rukuru & $1968 / 1969-2008 / 2009$ & $\circ$ & $\circ$ & ○ \\
\hline $9 \mathrm{~A} 2$ & Lufira & $1953 / 1954-2009 / 2010$ & $\circ$ & $\uparrow$ & $\circ$ \\
\hline 9A4 & Lufira & $1958 / 1959-2007 / 2008$ & $\downarrow$ & $\downarrow$ & $\circ$ \\
\hline 9A5 & Kalenje & $1970 / 1971-2006 / 2007$ & 0 & o & o \\
\hline 9B3 & Kaseye & $1970 / 1971-2007 / 2008$ & o & o & o \\
\hline 9B5 & Hanga & $1979 / 1980-2003 / 2004$ & 0 & o & o \\
\hline 9B6 & Songwe & $1981 / 1982-2007 / 2008$ & $\circ$ & $\circ$ & $\circ$ \\
\hline $9 \mathrm{~B} 7$ & Songwe & $1985 / 1986-2011 / 2012$ & $\circ$ & $\circ$ & $\circ$ \\
\hline $11 \mathrm{~A} 6$ & Lusangwisi & $1976 / 1977-1997 / 1998$ & $\circ$ & $\circ$ & $\circ$ \\
\hline $11 \mathrm{~A} 7$ & Masongola & 1976/1977-1997/1998 & $\circ$ & $\circ$ & $\circ$ \\
\hline $14 \mathrm{~A} 2$ & Luchenza & $1954 / 1955-2001 / 2002$ & $\circ$ & $\circ$ & $\circ$ \\
\hline $14 \mathrm{~A} 3$ & Chisombezi & $1962 / 1963-1999 / 2000$ & $\downarrow$ & $\downarrow$ & $\circ$ \\
\hline 14B2 & Thuchila & $1951 / 1952-2002 / 2003$ & $\circ$ & $\downarrow$ & $\circ$ \\
\hline $14 \mathrm{C} 2$ & Ruo & $1953 / 1954-2007 / 2008$ & $\uparrow$ & $\uparrow$ & $\uparrow$ \\
\hline $14 C 8$ & Lichenya & $1959 / 1960-2001 / 2002$ & $\uparrow$ & $\uparrow$ & 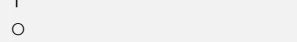 \\
\hline 14D1 & Ruo & $1980 / 1981-1990 / 1991$ & 0 & o & $\circ$ \\
\hline $15 \mathrm{~A} 4$ & Chirua & 1970/1971-1999/2000 & $\circ$ & $\circ$ & $\circ$ \\
\hline $15 \mathrm{~A} 8$ & Lingadzi & $1960 / 1961-2009 / 2010$ & $\circ$ & $\circ$ & $\circ$ \\
\hline 16E6 & Dwambadzi & $1972 / 1972-2008 / 2009$ & $\circ$ & $\circ$ & $\circ$ \\
\hline $16 \mathrm{~F} 1$ & Limphasa & 1970/1971-1990/1991 & $\circ$ & $\circ$ & $\circ$ \\
\hline $16 \mathrm{~F} 2$ & Luweya & 1952/1953-1993/1994 & $\circ$ & $\uparrow$ & $\circ$ \\
\hline $17 \mathrm{C} 6$ & Wovwe & 1969/1970-1992/1993 & $\downarrow$ & $\downarrow$ & $\circ$ \\
\hline $17 \mathrm{C} 10$ & Hara & $1974 / 1975-1988 / 1989$ & $\circ$ & $\circ$ & $\circ$ \\
\hline
\end{tabular}

[Where $\circ$ indicates no trend, $\uparrow$ indicates an increasing trend and $\downarrow$ indicates a decreasing trend].

\section{Conclusion}

The main aim of this study was to provide a comprehensive national assessment of temporal variations in groundwater discharge to rivers in Malawi using the Base Flow Index approach.

The study has shown that baseflow, a proxy indicator of groundwater discharge, in Malawi follows a seasonal pattern characterized by minimal difference between the annual and wet season baseflow, but with a significant increase in the dry season. This was evidenced through the average annual, wet season and dry season BFI found for Malawi, which was $0.57,0.52$ and 0.97 respectively. Considerable variability exists within the annual and wet season baseflow as shown by the minimum and maximum values, although minimal variability exists within the dry season BFI. Statistical trend analysis identified long-term behavioural changes in baseflow which varied spatially and temporally across the country over the assessment periods.
Overall, most gauging stations showed no trend in the annual, wet and dry season BFI. However, decreasing trends were found in some BFI data indicating unsustainable catchment practices, for example, over-abstraction of groundwater. In contrast, increasing trends were also evident in some catchments possibly due to noted conservation efforts.

These results enhance our understanding of baseflow in Malawi on a national scale and as such results will be of interest to the Malawian Government for use in water resources planning and management. The results will be particularly useful for measuring progress towards Sustainable Development Goal 6 Target 6.6 which is related to measuring changes over time in rivers and groundwater and imposed a 2020 deadline.

\section{Acknowledgements}

The authors would like to acknowledge financial support 
from the Scottish Government through the Climate Justice Fund: Water Futures Programme (research grant HN-CJF-03) and by the University of Strathclyde. They would also like to acknowledge our partners the Government of Malawi, specifically the Surface Water Division for providing data for this study.

\section{References}

[1] Singh, S. K.; Pahlow, M.; Booker, D. J.; Shankar, U.; Chamorro, A. Towards baseflow index characterisation at national scale in New Zealand. Journal of Hydrology 2019, $568,646-657$.

[2] Kelly, L.; Kalin, R. M.; Bertram, D.; Kanjaye, M.; Nkhata, M.; Sibande, H. Quantification of temporal variations in base flow index using sporadic river data: application to the Bua catchment, Malawi. Water 2019, 11, 901.

[3] World Bank. Assessment of the state of hydrological services $n$ developing countries; 2018.

[4] Houghton-Carr, H.; Fry, M.; Wallingford, U. The decline of hydrological data collection for the development of integrated water resource management tools in Southern Africa. IAHS publication 2006, 308, 51 .

[5] Tallaksen, L. M.; Van Lanen, H. A. Hydrological drought: processes and estimation methods for streamflow and groundwater; Elsevier, 2004; Vol. 48.

[6] Bosch, D. D.; Arnold, J. G.; Allen, P. G.; Lim, K.-J.; Park, Y. S Temporal variations in baseflow for the Little River experimental watershed in South Georgia, USA. Journal of Hydrology: Regional Studies 2017, 10, 110-121.

[7] Kelly, L.; Bertram, D.; Kalin, R.; Ngongondo, C. Characterization of Groundwater Discharge to Rivers in the Shire River Basin, Malawi. American Journal of Water Science and Engineering 2019, 5, 127-138.

[8] Brodie, R.; Sundaram, B.; Tottenham, R.; Hostetler, S.; Ransley, T. An adaptive management framework for connected groundwater-surface water resources in Australia. Bureau of Rural Sciences, Canberra 2007.

[9] International Hydrological Programme of UNESCO. Groundwater Resources Assessment under the Pressures of Humanity and Climate Changes GRAPHIC. 2006.

[10] Hughes, D. A.; Hannart, P. A desktop model used to provide an initial estimate of the ecological instream flow requirements of rivers in South Africa. Journal of Hydrology 2003, 270, 167-181.

[11] Beck, H. E.; van Dijk, A. I. J. M.; Miralles, D. G.; de Jeu, R. A.; Bruijnzeel, L. A. (Sampurno); McVicar, T. R.; Schellekens, J. Global patterns in base flow index and recession based on streamflow observations from 3394 catchments. Water Resources Research 2013, 49, 7843-7863.

[12] Ngongondo, C. S. An analysis of long-term rainfall variability, trends and groundwater availability in the Mulunguzi river catchment area, Zomba mountain, Southern Malawi. Quaternary International 2006, 148, 45-50.

[13] UNESCO Southern Africa FRIEND IHP-V Project 1.1 Technical Documents in Hydrology No. 15. Paris 1997.
[14] Kumambala, P. G. Sustainability of water resources development for Malawi with particular emphasis on North and Central Malawi (unpublished PhD thesis), 2010.

[15] Government of Malawi. National Water Resources Master Plan 2017. Annex 1: Surface Water Resources. 2017.

[16] Government of Malawi. Water Resources Investment Strategy. Component 1 - Water Resources Assessment. Annex II Surface Water 2011.

[17] Fraser, C. M.; Kalin, R. M.; Rivett, M. O.; Nkhata, M.; Kanjaye, M. A national approach to systematic transboundary aquifer assessment and conceptualisation at relevant scales: A Malawi case study. Journal of Hydrology: Regional Studies 2018.

[18] Government of Malawi. Water Resources Investment Strategy. Component 1 - Water Resources Assessment. Main Report 2011.

[19] Government of Malawi. Malawi Land Use Map. Forestry Commission 2018.

[20] Government of Malawi. Malawi Hydrogeological and Water Quality Atlas 2018. Ministry of Agriculture, Irrigation and Water Development 2018.

[21] Zuzani, P.; Ngongondo, C.; Mwale, F.; Willems, P. Examining trends of hydro-meteorological extremes in the Shire River Basin in Malawi. Physics and Chemistry of the Earth, Parts $A / B / C 2019$.

[22] Ngongondo, C.; Xu, C.-Y.; Gottschalk, L.; Alemaw, B. Evaluation of spatial and temporal characteristics of rainfall in Malawi: a case of data scarce region. Theoretical and applied climatology 2011, 106, 79-93.

[23] Banda, L. C.; Rivett, M. O.; Kalin, R. M.; Zavison, A. S.; Phiri, P.; Kelly, L.; Chavula, G.; Kapachika, C. C.; Nkhata, M.; Kamtukule, S.; others Water-Isotope Capacity Building and Demonstration in a Developing World Context: Isotopic Baseline and Conceptualization of a Lake Malawi Catchment. Water 2019, 11, 2600.

[24] Institute of Hydrology. Low Flow Studies Report No 3; Institute of Hydrology, Wallingford, UK, 1980.

[25] Morawietz, M. User's Guide BFI. Oslo: University of Oslo 1997.

[26] Mann, H. B. Nonparametric tests against trend. Econometrica: Journal of the Econometric Society 1945, 245-259.

[27] Kendall, M. G. Rank correlation methods; 4th ed.; Griffin, London, 1975.

[28] Addinsoft XLSTAT statistical and data analysis solution. Long Island, New York, USA 2019.

[29] mWater. Technology for Water and Health. https://www.mwater.co/ (accessed Aug 12, 2019).

[30] Miller, A.; Nhlema, M.; Kumwenda, S.; Mbalame, E.; Uka, Z.; Feighery, J.; Kalin, R. M. Evolving water point mapping to strategic decision making in rural Malawi. 2018.

[31] Kalin, R. M.; Mwanamveka, J.; Coulson, A. B.; Robertson, D. J.; Clark, H.; Rathjen, J.; Rivett, M. O. Stranded assets as a key concept to guide investment strategies for sustainable development goal 6. Water 2019, 11, 702 . 
[32] Truslove, J. P.; VM Miller, A.; Mannix, N.; Nhlema, M.; Rivett, M. O.; Coulson, A. B.; Mleta, P.; Kalin, R. M. Understanding the functionality and burden on decentralised rural water supply: Influence of Millennium Development Goal 7c coverage targets. Water 2019, 11, 494.

[33] Rivett, M. O.; Miller, A. V.; MacAllister, D. J.; Fallas, A.; Wanangwa, G. J.; Mleta, P.; Phiri, P.; Mannix, N.; Monjerezi, M.; Kalin, R. M. A conceptual model based framework for pragmatic groundwater-quality monitoring network design in the developing world: Application to the Chikwawa District, Malawi. Groundwater for Sustainable Development 2018, 6, 213-226.
[34] De Graaf, I. E.; Gleeson, T.; van Beek, L. R.; Sutanudjaja, E. H.; Bierkens, M. F. Environmental flow limits to global groundwater pumping. Nature 2019, 574, 90-94.

[35] Government of Malawi. National Irrigation Master Plan and Investment Framework. Ministry of Agriculture, Irrigation and Water Development 2015.

[36] Water, U. Integrated Monitoring Guide for Sustainable Development Goal 6 on Water and Sanitation-Targets and global indicators. 2017.

[37] SDG Tracker Sustainable Development Goals Clean Water and Sanitation https://sdg-tracker.org/water-and-sanitation (accessed 29-11/19). 